\title{
Front Matter: Volume 7447
}

, "Front Matter: Volume 7447," Proc. SPIE 7447, Videometrics, Range Imaging, and Applications X, 744701 (26 September 2009); doi:

10.1117/12.847192

SPIE Event: SPIE Optical Engineering + Applications, 2009, San Diego, California, SPIE. United States 


\section{PROCEEDINGS OF SPIE}

\section{Videometrics, Range Imaging, and Applications $X$}

Fabio Remondino

Mark R. Shortis

Sabry F. El-Hakim

Editors

2-3 August 2009

San Diego, California, United States

Sponsored and Published by

SPIE 
The papers included in this volume were part of the technical conference cited on the cover and title page. Papers were selected and subject to review by the editors and conference program committee. Some conference presentations may not be available for publication. The papers published in these proceedings reflect the work and thoughts of the authors and are published herein as submitted. The publisher is not responsible for the validity of the information or for any outcomes resulting from reliance thereon.

Please use the following format to cite material from this book:

Author(s), "Title of Paper," in Videometrics, Range Imaging, and Applications $X$, edited by Fabio Remondino, Mark R. Shortis, Sabry F. El-Hakim, Proceedings of SPIE Vol. 7447 (SPIE, Bellingham, WA, 2009) Article CID Number.

ISSN 0277-786X

ISBN 9780819477378

Published by

SPIE

P.O. Box 10, Bellingham, Washington $98227-0010$ USA

Telephone +1 3606763290 (Pacific Time) · Fax +1 3606471445

SPIE.org

Copyright (C) 2009, Society of Photo-Optical Instrumentation Engineers

Copying of material in this book for internal or personal use, or for the internal or personal use of specific clients, beyond the fair use provisions granted by the U.S. Copyright Law is authorized by SPIE subject to payment of copying fees. The Transactional Reporting Service base fee for this volume is $\$ 18.00$ per article (or portion thereof), which should be paid directly to the Copyright Clearance Center (CCC), 222 Rosewood Drive, Danvers, MA 01923. Payment may also be made electronically through CCC Online at copyright.com. Other copying for republication, resale, advertising or promotion, or any form of systematic or multiple reproduction of any material in this book is prohibited except with permission in writing from the publisher. The CCC fee code is 0277-786X/09/\$18.00.

Printed in the United States of America.

Publication of record for individual papers is online in the SPIE Digital Library.

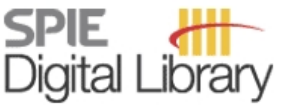

SPIEDigitalLibrary.org

Paper Numbering: Proceedings of SPIE follow an e-First publication model, with papers published first online and then in print and on CD-ROM. Papers are published as they are submitted and meet publication criteria. A unique, consistent, permanent citation identifier (CID) number is assigned to each article at the time of the first publication. Utilization of CIDs allows articles to be fully citable as soon they are published online, and connects the same identifier to all online, print, and electronic versions of the publication. SPIE uses a six-digit CID article numbering system in which:

- The first four digits correspond to the SPIE volume number.

- The last two digits indicate publication order within the volume using a Base 36 numbering system employing both numerals and letters. These two-number sets start with 00, 01, 02, 03, 04 , 05, 06, 07, 08, 09, OA, OB ... 0Z, followed by 10-1Z, 20-2Z, etc.

The CID number appears on each page of the manuscript. The complete citation is used on the first page, and an abbreviated version on subsequent pages. Numbers in the index correspond to the last two digits of the six-digit CID number. 


\section{Contents}

vii Conference Committee
ix Introduction

SESSION 1 RANGE SYSTEMS I

744702 Range calibration for terrestrial laser scanners and range cameras (Invited Paper) [7447-01] N. Pfeifer, C. Ressl, W. Karel, Vienna Univ. of Technology (Austria)

744703 Range sensors on marble surfaces: quantitative evaluation of artifacts [7447-02] G. Guidi, Politecnico di Milano (Italy); F. Remondino, FBK Trento (Italy); M. Russo, Politecnico di Milano (Italy); A. Spinetti, Univ. of Florence (Italy)

744704 Proposed traceable structural resolution protocols for 3D imaging systems [7447-03] D. MacKinnon, J.-A. Beraldin, L. Cournoyer, B. Carrier, F. Blais, National Research Council Canada (Canada)

\section{SESSION 2 SYSTEMS DEVELOPMENT}

744705 Real-time phase-stamp range finder with improved accuracy [7447-05]

A. Kimachi, Osaka Electro-Communication Univ. (Japan)

744706 Application of inverse square law for 3D sensing [7447-06]

S. Gurbuz, NICT Universal Media Research Ctr. (Japan)

\section{SESSION 3 INDUSTRIAL/SYSTEM METROLOGY}

744708 Performance study of non-contact surface measurement technology for use in an experimental fusion device [7447-08]

A. Brownhill, Univ. College London (United Kingdom); R. Brade, Culham Science Ctr. (United Kingdom); S. Robson, Univ. College London (United Kingdom)

7447 OA Efficient embedded plate position measurement system for large plant construction [7447-11]

H. Yokoyama, Y. Yamamoto, S. Ebata, T. Makita, Hitachi Plant Technologies, Ltd. (Japan)

7447 OB A real-time 3D scanning system for pavement rutting and pothole detections [7447-12]

Q. Li, M. Yao, X. Yao, W. Yu, B. Xu, The Univ. of Texas at Austin (United States) 
7447 OC DTM generation in forested area using multiple return pulses from airborne laser scanner [7447-13]

T. Kakiuchi, Aero Asahi Corp. (Japan); H. Chikatsu, Tokyo Denki Univ. (Japan)

7447 OD Classification of mobile terrestrial laser point clouds using semantic constraints [7447-16] S. Pu, International Institute for Geo-Information Science and Earth Observation (Netherlands); Q. Zhan, Wuhan Univ. (China)

\section{SESSION 5 IMAGE SEQUENCE ANALYSIS/TRACKING}

7447 OE Markerless motion capture: the challenge of accuracy in capturing animal motions through model based approaches (Invited Paper) [7447-17]

E. Gambaretto, Animotion Inc. (United States) and Politecnico di Milano (Italy); S. Corazza, Animotion Inc. (United States)

7447 OF Automated tracking of a figure skater by using PTZ cameras [7447-18]

T. Haraguchi, T. Taki, J. Hasegawa, Chukyo Univ. (Japan)

\section{SESSION 6 SYSTEM CALIBRATION AND CHARACTERIZATION}

$7447 \mathrm{OH} \quad$ Comparative evaluation of consumer grade cameras and mobile phone cameras for close range photogrammetry [7447-20]

H. Chikatsu, Y. Takahashi, Tokyo Denki Univ. (Japan)

7447 Ol Statistical analysis of measurement processes for time-of-flight cameras [7447-21]

F. Mufti, R. Mahony, Australian National Univ. (Australia)

7447 OJ Performance evaluation of macro lens in digital close range photogrammetry [7447-22]

H. Yanagi, H. Chikatsu, Tokyo Denki Univ. (Japan)

7447 OK Three-dimensional object recognition using a monoscopic camera system and CAD geometry information [7447-23]

A. Cefalu, J. Boehm, Univ. Stuttgart (Germany)

\section{SESSION 7 APPLICATIONS}

$7447 \mathrm{OL} \quad$ Payload systems and tracking algorithms for photogrammetric measurement of parachute shape [7447-24]

M. R. Shortis, RMIT Univ. (Australia); S. Robson, Univ. College London (United Kingdom); T. W. Jones, B. Lunsford, NASA Langley Research Ctr. (United States); J. F. Oliveira, INESC-ID (Portugal)

$7447 \mathrm{OM}$ Combined use of photogrammetric and computer vision techniques for fully automated and accurate 3D modeling of terrestrial objects [7447-25]

L. Barazzetti, Politecnico di Milano (Italy); F. Remondino, Brian Kessler Foundation (Italy); M. Scaioni, Politecnico di Milano (Italy) 
7447 ON Analysis of keratoscopic images for detecting fixational eye movements and ocular surface deformation [7447-26]

M. Kowalska, Wroclaw Univ. of Technology (Poland); D. Mas, Univ. of Alicante (Spain); H. Kasprzak, Wroclaw Univ. of Technology (Poland)

Author Index 
Downloaded From: https://www.spiedigitallibrary.org/conference-proceedings-of-spie on 26 Apr 2023

Terms of Use: https://www.spiedigitallibrary.org/terms-of-use 


\title{
Conference Committee
}

\author{
Program Track Chair
}

Khan M. Iftekharuddin, The University of Memphis (United States)

Conference Chairs

Fabio Remondino, Fondazione Bruno Kessler (Italy)

Mark R. Shortis, RMIT University (Australia)

Sabry F. El-Hakim, National Research Council Canada (Canada)

Program Committee

J. Angelo Beraldin, National Research Council Canada (Canada)

Jan Boehm, Universität Stuttgart (Germany)

Hirofumi Chikatsu, Tokyo Denki University (Japan)

Nicola D'Apuzzo, Homometrica Consulting (Switzerland)

Armin Gruen, ETH Zürich (Switzerland)

Gabriele Guidi, Politecnico di Milano (Italy)

Henrik G. A. Haggren, Helsinki University of Technology (Finland)

Derek D. Lichti, University of Calgary (Canada)

Hans-Gerd Maas, Technische Universität Dresden (Germany)

Norbert Pfeifer, Technische Universität Wien (Austria)

Stuart Robson, University College London (United Kingdom)

\section{Session Chairs}

1 Range Systems I

Mark R. Shortis, RMIT University (Australia)

2 Systems Development

Fabio Remondino, Fondazione Bruno Kessler (Italy))

3 Industrial/System Metrology

Mark R. Shortis, RMIT University (Australia)

$4 \quad$ Range Systems II

Norbert Pfeifer, Technische Universität Wien (Austria)

5 Image Sequence Analysis/Tracking

Fabio Remondino, Fondazione Bruno Kessler (Italy)

6 System Calibration and Characterization

Mark R. Shortis, RMIT University (Australia) 
$7 \quad$ Applications

Norbert Pfeifer, Technische Universität Wien (Austria) 


\section{Introduction}

The Videometrics, Range Imaging, and Applications $X$ conference is the twelfth in a series commenced in 1991. Under the auspices of the International Society for Optical Engineering (SPIE), Sabry El-Hakim arranged the first conference on Industrial Vision Metrology, held in Winnipeg, Canada. Based on the success of this first venture into an emerging discipline, the conference was renamed Videometrics and held in conjunction with the SPIE Photonics East group of conferences in Boston and Philadelphia during 1992-1995. Videometrics was then re-located to become part of SPIE Photonics West, held annually in California. The conferences have been held once in San Diego in 1997, then twice in San Jose in 1999 and 2001 (given the longer title of Videometric and Optical Methods for 3D Shape Measurement), then moved to Santa Clara in 2003, and moved back to San Jose in 2005 and 2007.

For more than two decades, the Videometrics conference series has been providing a unique forum for computer vision, image processing and photogrammetry researchers and practitioners to present the latest advances in precise 3D measurement and modeling from imaging and range sensors. This conference originally focused on the metric performance of sensors and algorithms to produce the most accurate and reliable geometric measurements and models. Topics such as sensor calibration, performance evaluation and accurate object reconstruction were predominant. This has now been expanded to encompass all phases of 3D optical and range imaging and modeling of real scenes, including automation of data collection and processing, improving the visual quality and realism, visualization, animation and data management for real-time manipulation. This is in response to the fast growing interest in 3D imaging and modeling technology, and the increased demand of these models in applications such as rapid product development, virtual museums, documentation of monuments and architecture for cultural heritage, marketing and tourism, human body modeling, medicine, and exploration of remote and hazardous sites, to name just a few.

The 2009 meeting will be held once more at San Diego, but this time within SPIE Optics + Photonics, as part of the program track on Image and Signal Processing within the Optical Engineering + Applications conferences. The group of conferences that comprise Image and Signal Processing combines the disciplines of optical design, image processing, advanced metrology and remote sensing. Optics + Photonics in total comprises 80 technical conferences and 3100 papers, around 100 short courses and workshops, and a technical exhibit with more than 100 exhibitors. Although the individual conferences generally span one to three days, the schedule is staggered so that there is a selection of 20-30 technical sessions at any time during the meeting. Attendees thereby get the benefit of 
seeing the broader extent of discipline areas allied to Videometrics, with the additional bonus of approximately 30 plenary presentations.

Videometrics, Range Imaging, and Applications X will have two invited speakers on range sensor calibration and markerless motion capture. In addition there will be technical sessions related to range measurement instruments, systems characterization and development, industrial metrology, image sequence analysis and image-based applications.

The Chairs of Videometrics welcome and acknowledge the efforts of the authors, presenters and audience in maintaining the high level of interest in Videometrics and contributing to the success of the meeting.

Fabio Remondino

Mark R. Shortis Sabry F. El-Hakim 